\title{
KESULITAN-KESULITAN GURU DALAM IMPLEMENTASI KTSP MATA PELAJARAN SEJARAH SEKOLAH MENENGAH ATAS (Penelitian di SMA N I Prambanan Klaten)
}

\author{
Terry Irenewaty, M.Hum. \\ (Dosen Pendidikan Sejarah, FIS, UNY) \\ Email: terry_irenewaty@yahoo.com
}

\begin{abstract}
ABSTRAK
Penelitian ini bertujuan untuk: (1) mengetahui realitas pembelajaran sejarah di SMA Negeri I Prambanan Klaten dan (2) mengetahui kesulitan-kesulitan guru sejarah dalam implementasi Kurikulum Tingkat Satuan Pendidikan (KTSP) mata pelajaran sejarah. Metode penelitian ini menggunakan pendekatan kualitatif deskriptif yang bersifat naturalistik. Hasil penelitian menunjukkan bahwa: (1) pembelajaran sejarah di SMA N I Prambanan Klaten menunjukkan kecenderungan pembelajaran yang sifatnya rutinitas, kurang memperhatikan kualitas proses dan hasil yang substantif sesuai dengan rumusan tujuan pembelajaran sejarah sebagaimana termuat dalam Permendiknas No 22 tahun 2006, (2) dalam implementasi KTSP guru sejarah masih menemukan banyak kesulitan-kesulitan baik secara teoritik maupun praktik. Adapun kesulitankesulitan yang dialami guru dalam pembelajaran sejarah yang menyangkut implementasi KTSP adalah: (1) kesulitan dalam mengembangkar Rencana Pelaksanaan Pembelajaran, (2) menyiapkan atau mengemas materi pembelajaran, (3) menggunakan media yang mtakhir, (4) memfokuskan perhatian siswa, (5) menerapkan variasi metode pembelajaran, (6) memberikan umpan balik, (7) memberikan rangsangan motivasi, (8) mengevaluasi pembelajaran secara komprehensif, dan (9) mengembangkan secara keseluruhan KTSP itu sendiri.
\end{abstract}

Kata Kunci: realitas, pembelajaran sejarah, KTSP.

ABSTRACK

This study aims to: (1) know the reality of the teaching of history in SMA I Prambanan Klaten and (2) know the difficulties of history teachers in the implementation of the Education Unit Level Curriculum (KTSP) especially for history subject. This research method used descriptive qualitative approach with naturalistic character. The results showed that: (1) the teaching of history in SMA N I Prambanan Klaten showed a trend of learning that are routine, lack of attention to the quality of the process and the results of substantive accordance with the formulation of the objectives of teaching history as contained in the Ministerial Regulation Number 22 year 2006, (2) in KTSP implementation, history teachers still find many difficulties both theoretical and practical. The difficulties experienced by teachers in the teaching of history concerning the implementation of the curriculum are: (1) difficulties in developing lesson plans, (2) prepare or pack of learning materials, (3) using the modern media, (4) to focus the attention of students, (5) implement a variety of learning methods, (6) provide feedback, (7) provide motivation stimulation, (8) evaluate learning comprehensively, and (9) develop the overall of curriculum itself.

Keywords: reality, learning history, KTSP.

Terry Irenewaty, Kesulitan-Kesulitan Guru dalam Implementasi KTSP Mata Pelajaran Sejarah Sekolah Menengah Atas (SMA) 


\section{Pendahuluan}

Sistem pengajaran sebagai bagian integral dari sistem kegiatan pendidikan, merupakan fenomena yang harus diperbaiki dan dikembangkan oleh pihak-pihak yang terkait dan berkepentingan. Hal ini menyangkut kurikulum, metode, media pengajaran, materi pengajaran, kualitas guru, dan lain sebagainya sehingga tercipta sistem pengajaran yang baik dan berorientasi ke masa depan. Dengan demikian perlu dikembangkan prinsip-prinsip belajar yang berorientasi pada masa depan, dan menjadikan peserta didik tidak hanya sebagai objek belajar tetapi juga subjek dalam belajar. Pendidikan tidak lagi berpusat pada lembaga atau guru yang hanya akan mencetak para lulusan yang kurang berkualitas, melainkan harus berpusat pada siswa sebagai pusat belajar, yang tidak hanya "disuapi" dengan materi pengajaran dari guru-guru, tetapi juga harus memberikan kesempatan kepada para siswa untuk bersikap kreatif dan mengembangkan diri sesuai dengan potensi intelektual yang dimilikinya.

Sistem pengajaran yang baik seharusnya dapat membantu mencapai tujuan-tujuan belajarnya. Meskipun proses belajar mengajar tidak dapat sepenuhnya berpusat pada siswa seperti pada pendidikan terbuka, tetapi yang perlu dicermati adalah bahwa pada hakekatnya siswalah yang harus belajar dan mengembangkan diri. Dengan demikian proses belajar mengajar perlu berorientasi pada kebutuhan dan kemampuan siswa. Kegiatan-kegiatan yang dilakukan dalam proses belajar mengajar harus dapat memberikan pengalaman belajar yang menyenangkan dan berguna bagi siswa. Guru perlu memberikan bermacam-macam situasi belajar yang memadai untuk materi yang disajikan, dan menyesuaikannya dengan kemampuan serta karakteristik siswa sebagai subjek-didik.

Mengajar merupakan suatu aktivitas profesional yang memerlukan keterampilan tingkat tinggi dan mencakup hal-hal yang berkaitan dengan pengambilan keputusankeputusan (Winata Putera, 1992 : 86). Sekarang ini guru lebih dituntut untuk berfungsi sebagai pengelola proses belajar mengajar yang melaksanakan tugas yaitu dalam merencanakan, mengatur, mengarahkan, dan mengevaluasi. Keberhasilan dalam belajar mengajar sangat tergantung pada kemampuan guru dalam merencanakan, yang mencakup antara lain menentukan tujuan belajar siswa, bagaimana caranya agar siswa mencapai tujuan tersebut, sarana apa yang diperlukan, dan lain sebagainya. Dalam hal mengatur, yang dilakukan pada waktu implementasi apa yang telah direncanakan dan mencakup pengetahuan tentang bentuk dan macam kegiatan yang harus dilaksanakan, bagaimana semua komponen dapat bekerjasama dalam mencapai tujuan-tujuan yang telah ditentukan. Guru bertugas untuk mengarahkan, memberikan motivasi, dan memberikan inspirasi kepada siswa untuk belajar.

Dalam proses belajar mengajar, guru perlu mengadakan keputusan-keputusan, misalnya metode apakah yang perlu dipakai untuk mengajar mata pelajaran tertentu, alat dan media apakah yang diperlukan untuk membantu siswa membuat suatu catatan, melakukan praktikum, menyusun makalah diskusi, atau cukup hanya dengan mendengar ceramah guru saja. Dalam proses belajar mengajar guru selalu dihadapkan pada bagaimana melakukannya, dan mengapa hal tersebut perlu dilakukan. Begitu juga dalam hal evaluasi atau penilaian dihadapkan pada bagaimana sistem penilaian yang digunakan, 
bagaimana kriterianya, dan bagaimana pula kondisi siswa sebagai subjek belajar yang memerlukan nilai itu.

Dalam rangka pengembangan pengajaran sejarah agar lebih fungsional dan terintegrasi dengan berbagai bidang keilmuan lainnya, maka terdapat berbagai bidang yang seyogianya mendapat perhatian, yaitu: pertama, untuk menjawab tantangan masa depan, kreativitas dan daya inovatif diperlukan agar bangsa Indonesia bukan sekedar manjadi konsumen IPTEK, konsumen budaya, maupun penerima nilainilai dari luar secara pasif, melainkan memiliki keunggulan kompetitif dalam hal penguasaan IPTEK. Oleh karenanya, kreativitas perlu dikembangkan melalui penciptaan situasi proses belajar mengajar yang kondusif di mana guru mendorong vitalitas dan kreativitas siswa untuk mengembangkan diri. Siswa perlu diberi kesempatan untuk belajar dengan daya intelektualnya sendiri, melalui proses rangsangan-rangsangan baik yang berupa pertanyaan-pertanyaan maupun penugasan, sehingga siswa dapat melihat suatu hal dari berbagai sudut pandang dan dapat menemukan berbagai alternatif pemecahan masalah yang dihadapi.

Kedua, siswa akan dapat mengembangkan daya kreativitasnya apabila proses belajar mengajar dilaksanakan secara terencana untuk meningkatkan dan membangkitkan upaya untuk kompetitif. Oleh karena itu, proses belajar mengajar yang memberi peluang kepada siswa untuk menyelesaikan tugas secara kompetitif perlu disosialisasikan, kemudian juga perlu adanya penghargaan yang layak kepada mereka yang berprestasi. Hal ini akan berdampak positif terhadap terbentuknya rasa percaya diri pada siswa. Pada gilirannya, pengalaman ini selanjutnya dapat menjaga proses pembentukan kemandirian. Dalam hal ini siswa juga perlu dilibatkan dalam proses belajar mengajar yang memberikan pengalaman bagaimana siswa bekerja sama dengan siswa yang lain seperti dalam hal berdiskusi, membuat artikel kelompok, pengamatan, wawancara, dan sebagainya untuk dikerjakan secara kelompok. Pengalaman belajar seperti ini selanjutnya akan dapat membentuk sikap kooperatif dan ketahanan bersaing dengan pengalaman nyata untuk dapat menghargai segala kelebihan dan kelemahan masing-masing.

Ketiga, dalam proses pengembangan kematangan intelektualnya, siswa perlu dipacu kemampuan berfikirnya secara logis dan sistematis. Dalam proses belajar mengajar, guru harus memberi arahan yang jelas agar siswa dapat memecahkan suatu persoalan secara logis dan ilmiah. Oleh karena itu siswa perlu dilibatkan secara aktif dalam proses belajar mengajar melalui pemberian tugas. Tugas tidak terlalu berat tetapi dapat memacu daya berfikir siswa. Salah satu aspek yang penting adalah bagaimana siswa dapat terlatih berpikir secara deduktif-induktif. Artinya, dalam proses belajar mengajar siswa perlu diarahkan sedemikian rupa sehingga siswa dapat mempelajari materi pelajaran melalui pengalaman. Dengan cara seperti ini mereka dapat secara langsung dihadapkan pada suatu realita di lapangan. Seperti halnya siswa disediakan mata pelajaran yang bersifat khusus yang memberikan pengalaman, berdiskusi, penelitian, dan lain sebagainya yang diarahkan untuk menarik kesimpulan baik deduktif maupun induktif.

Keempat, siswa harus diberi internalisasi dan keteladanan, dimana siswa dapat berperan aktif dalam kegiatan belajar mengajar. Fenomena ini dalam hal-hal tertentu dapat membentuk semangat loyalitas, toleransi, dan kemampuan adaptabilitas yang tinggi. Dalam hal 
pendekatan ini perlu diselaraskan dengan kegiatan proses belajar mengajar yang memberi peluang kepada mereka untuk berprakarsa secara dinamis dan kreatif. Dengan demikian akan tercapai kualitas proses dan hasil belajar yang berorientasi pada pencapaian tujuan yang jelas, dengan melibatkan siswa secara maksimal melalui berbagai kegiatan yang konstruktif, sehingga pengalaman tersebut dapat mengantar siswa dalam suatu proses belajar yang kondusif dan kreatif.

Untuk menjawab tantangan ini, maka Kurikulum Tingkat Satuan Pendidikan (KTSP), harus dikembangkan dan diimplementasikan secara maksimal dalam rangka meningkatkan kualitas proses dan hasil belajar. Komponen KTSP yang terdiri dari ketrampilan, sikap dan nilai, akan mewarnai kegiatan belajar mengajar yang impresif, dan dapat mencapai tujuan pendidikan nasional secara signifikan. Penerapan KTSP secara utuh dan menyeluruh, sangat tergantung pada persepsi dan partisipasi guru sebagai pelaksana kurikulum, dan kreatifitas siswa dalam proses belajar mengajar. Subjek-didik yang terdiri dari guru dan siswa, merupakan komponen belajar mengajar yang sangat menentukan keberhasilan dari tujuan pembelajaran. Disamping itu persepsi dan partisipasi guru yang positif terhadap kurikulum baru, akan memberikan angin segar bagi penyelenggaraan pendidikan yang bermakna. Selanjutnya penelitian ini mengkaji tentang kendala-kendala dalam penerapan Kurikulum Tingkat Satuan Pendidikan mata pelajaran sejarah di Sekolah Menengah Pertama dalam hal ini di SMA Negeri I Prambanan Klaten.

\section{Metodologi Penelitian}

Metodologi merupakan konsep teoritik yang membahas mengenai berbagai metode atau ilmu metode-metode, yang dipakai dalam penelitian. Sedangkan metode merupakan bagian dari metodologi, yang diinterpretasikan sebagai teknik dan cara dalam penelitian, misalnya teknik observasi, metode pengumpulan sumber (heuristik), teknik wawancara, analisis isi, dan lain sebagainya. Berbagai hal yang berkaitan dengan metodologi penelitian yang akan digunakan dalam penelitian ini dapat dijelaskan sebagai berikut.

- Lokasi Penelitian

Penelitian ini dilaksanakan di SMA Negeri I Prambanan Klaten dan difokuskan pada kendala-kendala dalam penerapan Kurikulum Tingkat Satuan Pendidikan mata pelajaran sejarah.

- Bidang Penelitian

Bidang masalah yang akan dikaji adalah masalah pendidikan yang berhubungan dengan perkembangan kegiatan belajar mengajar sejarah selama ini, persepsi dan partisipasi guru terhadap pengajaran sejarah berbasis kompetensi, pesepsi dan partisipasi guru berkaitan dengan latar belakang pendidikan yang dimilikinya, serta kendala-kendala dalam penerapan Kurikulum Tingkat Satuan Pendidikan mata pelajaran sejarah.

- Bentuk/Strategi Penelitian

Berdasarkan permasalahan yang diajukan dalam penelitian ini, yang lebih mengutamakan pada masalah proses dan makna/persepsi, maka jenis penelitian dengan strateginya yang cocok dan relevan adalah penelitian kualitatif deskriptif. Dengan penelitian ini diharapkan dapat mengungkap berbagai informasi kualitatif dengan deskripsianalisis yang teliti dan penuh makna, yang juga tidak menolak informasi kuantitatif dalam bentuk angka maupun jumlah. Pada tiap-tiap obyek akan dilihat kecenderungan, pola pikir, 
ketidakteraturan, serta tampilan perilaku dan integrasinya sebagaimana dalam studi kasus genetik (Muhadjir, 1996: 243). Strategi yang digunakan dalam penelitian ini adalah studi kasus (case study). Karena permasalahan dan fokus penelitian sudah ditentukan dalam proposal sebelum terjun ke lapangan, maka jenis strategi penelitian ini secara lebih spesifik dapat disebut sebagai studi kasus terpancang (embedded case study research)(Yin, 1987: 136).

- Sumber Data

Dalam penelitian kualitatif, peneliti berhadapan dengan data yang bersifat khas, unik, idiocyncratic, dan multiinterpretable (Waluyo, 2000: 20). Data yang paling penting untuk dikumpulkan dan dikaji dalam penelitian ini adalah data kualitatif. Data kualitatif tidak bersifat nomotetik (satu data satu makna) seperti dalam pendekatan kuantitatif atau positivisme. Untuk itu, data-data kualitatif perlu ditafsirkan agar mendekati kebenaran yang diharapkan (Waluyo, 2000: 20). Adapun jenis sumber data yang digunakan dalam penelitian ini meliputi: informan atau nara sumber yang terdiri dari guru dan siswa, tempat dan aktivitas yang terdiri dari kegiatan proses belajar mengajar di SMA Negeri I Prambanan Klaten, dan teks yang berupa arsip dan dokumen resmi mengenai program pengajaran, kurikulum, dan catatan-catatan lain yang relevan.

- Teknik Pengumpulan Data

Sesuai dengan bentuk penelitian kualitatif dan juga jenis sumber data yang dimanfaatkan, maka teknik pengumpulan data yang akan digunakan dalam penelitian ini adalah: wawancara mendalam (in depth interviewing), observasi langsung dan mencatat dokumen (content analysis).
- Teknik Cuplikan (Sampling)

Teknik cuplikan yang digunakan dalam penelitian ini adalah "Purposive Sampling" (Sutopo, 1996 : 138), atau lebih tepat disebut sebagai cuplikan dengan criterion-based selection yang tidak didapat ditemukan lebih dulu secara acak. (Moleong, 1999:165-166). Dalam hal ini peneliti memilih informan yang dianggap "mengetahui permasalahan yang dikaji" (dapat dipercaya informasinya). Penelitian diawali dengan memilih informan, dalam hal ini informan yang paling mengetahui fokus penelitian, kemudian dikembangkan sesuai dengan kebutuhan untuk memperoleh data (Patton, 1980:38). Adapun yang dijadikan sampel dalam penelitian ini adalah beberapa siswa yang dianggap mengerti permasalahan yang akan diteliti. Oleh karena itu responden yang diambil dalam penelitian ini adalah kepala sekolah, 2 guru sejarah, dan 8 orang siswa sehingga jumlah keseluruhan responden sebanyak 11 responden.

- Validitas Data

Guna menjamin dan mengembangkan validitas data yang dikumpulkan dalam penelitian ini, teknik pengembangan validitas data yang akan digunakan adalah teknik Triangulasi (Pattom, 1980 : 100), yang terdiri dari triangulasi data atau sumber, teori dan metode. Selain itu peneliti juga akan mengembangkan validitas data dengan teknik informan review.

- Teknik Analisis

Teknik analisis yang digunakan dalam penelitian ini adalah analisis interaktif (Miles dan Huberman, 1984). Dalam model analisis ini, tiga komponen analisisnya yaitu reduksi data, sajian data, dan penarikan kesimpulan atau verivikasi, aktivitasnya dilakukan dalam bentuk 
interaktif dengan proses pengumpulan data sebagai suatu proses yang berlanjut, berulang, dan terus-menerus hingga membentuk sebuah siklus. Peneliti selalu membuat reduksi data dan sajian data samapai penyusunan kesimpulan. Peneliti menyusun pemahaman arti segala peristiwa yang disebut reduksi data dan diikuti penyusunan data yang berupa ceritera secara sistematis. Reduksi dan sajian data ini disusun pada saat peneliti mendapatkan unit data yang diperlukan dalam penelitian. Pengumpulan data terakhir peneliti mulai melakukan usaha menarik kesimpulan dengan menarik verifikasi berdasarkan reduksi dan sajian data. Jika permasalahan yang diteliti belum terjawab dan atau belum lengkap, maka peneliti harus melengkapi kekurangan tersebut di lapangan terlebih dahulu. Secara skematis proses analisis interaktif ini dapat digambarkan sebagai berikut.

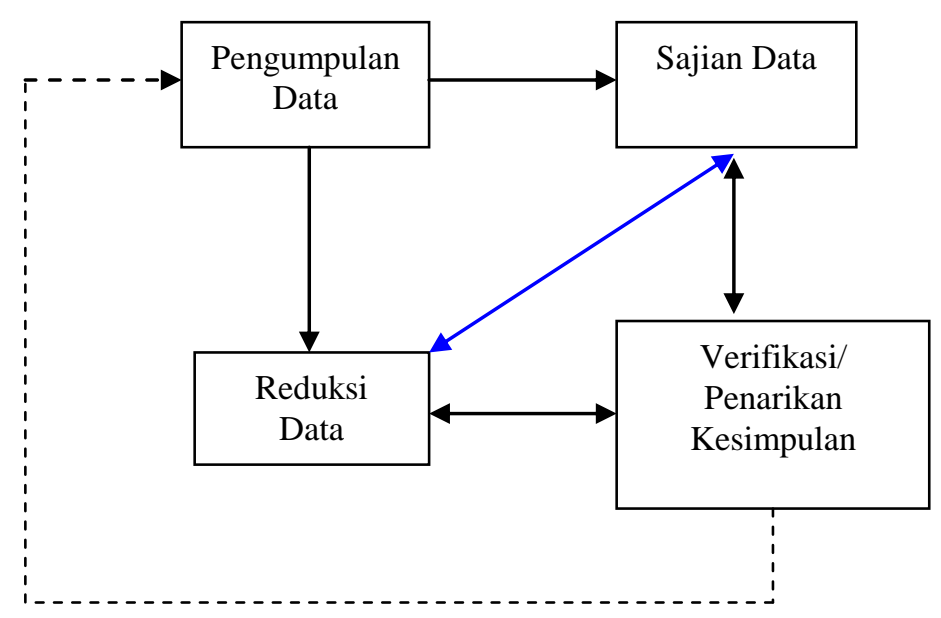

Gambar 1. Model Analisis Interaktif Milles dan Hubberman

\section{Hasil Penelitian dan Pembahasan Gambaran Umum SMA Negeri I Prambanan Klaten}

SMA N 1 Prambanan Klaten mulai berdiri pada tanggal 20 November 1984.
Awal berdirinya sekolah tersebut masih menumpang tempat atau gedung di SD Prambanan II yang terletak di desa Tlogo, Prambanan Klaten. Pada waktu itu jumlah siswa baru ada tiga kelas umum untuk kelas 1, kemudian di tahun ajaran berikutnya yaitu tahun ajaran 1984/1985 bertambah tiga kelas untuk kelas 2 dan tahun ajaran 1985/1986 bertambah lagi tiga kelas untuk kelas 3. Pada tahun ajaran 1986/1987 gedung SMA Negeri 1 Prambanan dipindahkan ke Unit Gedung Baru di desa Dengkok, tepatnya di Jalan Manisrenggo, Prambanan Klaten. Status tempat berdirinya gedung adalah milik sendiri atau tanah sendiri. Gedung berdiri tidak melalui pemda, tetapi langsung berdiri melalui ijin dari provinsi (Profil SMA N I Prambanan, 2012: 1).

Tahun ajaran 1987/1988 jumlah keseluruhan gedung SMA N 1 Prambanan adalah 9 gedung dengan komposisi kelas I berjumlah 3 kelas, kelas II berjumlah tiga kelas yaitu 1 kelas IPA dan 2 kelas IPS, dan kelas III berjumlah tiga kelas yaitu 1 kelas IPA dan 2 kelas IPS. Tahun ajaran berikutnya jumlah siswa baru terus bertambah sampai tahun ajaran sekarang ini yaitu tahun ajaran 2012/2013, dan sampai sekarang jumlah ruangan kelas ada 21 kelas dengan komposisi kelas X ada 7 kelas, kelas XI ada 7 kelas, dan kelas XII ada 7 kelas juga. Tahun ajaran 2012/2013 SMA N I Prambanan Klaten menerima mahasiswa Praktik dari Universitas Negeri Yogyakarta. Nama dari sekolah disesuaikan dengan daerah atau lokasi gedung, dan karena sekolah terletak di kecamatan Prambanan maka sekolah diberi nama SMA N 1 Prambanan, Klaten. Cikal bakal berdirinya SMA N 1 Prambanan adalah Bapak Hariyanto dan Bapak Sri Purwanta. Gedung SMA N 1 Prambanan Klaten diresmikan oleh Departemen Pendidikan dan Kebudayaan Republik Indonesia pada 
tanggal 18 Februari 1986 oleh Mentri Pendidikan dan Kebudayaan Prof.Dr. Fuad Hasan. Sekolah SMA N 1 Prambanan adalah sekolah yang dengan status akreditasi A (Profil SMA N I Prambanan Klaten, 2012).

Kondisi fisik sekolah pada umumnya sudah baik dan memenuhi syarat untuk menunjang proses pembelajaran meskipun dapat dikatakan bangunan sekolah telah berusia tua. Selain itu SMA Negeri 1 Prambanan Klaten memiliki fasilitas-fasilitas yang cukup memadai guna menunjang proses pembelajaran, seperti ruang kelas, laboratorium fisika dan biologi, kimia, bahasa, TI, ruang kantor, ruang kepala sekolah, dan ruang atau gedung penunjang lainnya. Sekolah ini berada di dekat jalan raya Manisrenggo yang terletak 2 kilometer dari jalan raya Jogja-Solo, yang dilalui oleh bus jalur perkotaan sehingga mudah dijangkau dari arah manapun.

Adapun visi dan misi SMA N I Prambanan Klaten dalam rangka menjalankan proses kegiatan belajar mengajar di SMA N I Prambanan Klaten mengemban visi dan misi yakni: visinya adalah terciptanya tamatan yang terdidik, terlatih, berkominikasi, berbudaya, dan berbudi pekerti. Sedangkan misinya adalah: menumbuhkan minat agar memiliki motivasi seni budaya bangsa; mendorong siswa agar memiliki kemampuan berkomunikasi dengan bahasa daerah dan bahsa asing; meningkatkan kesadaran akan lahirnya seni budaya bangsa; menumbuhkan loyalitas terhadap budaya bangsa; meningkatkan profesionalisme guru. Sedangkan tujuan dari sekolah SMA N 1 Prambanan adalah: siswa dapat berkomunikasi dalam bahasa daerah (Jawa) dan bahasa asing (Inggris, Prancis, Jerman, dan Jepang) baik individu maupun kelompok, siswa mampu mendemonstrasikan budaya lewat tari; melalui kemampuan yang dimiliki tersebut, siswa dapat menopang kehidupannya; meningkatkan manajemen sekolah sehingga lengkap aman, mudah dicari, dan digunakan; menciptakan personil sekolah yang siap melaksanakan proses pembelajaran yang berorientasi kebutuhan; menciptakan siswa yang mampu bersaing dalam era globalisasi (Frofil SMA Negeri I Prambanan Klaten, 2012).

\section{Realitas Pembelajaran Sejarah di SMA N I Prambanan}

Penelitian ini dilaksanakan di SMA Negeri 1 Prambanana Klaten dengan melibatkan responden kepala sekolah, 2 guru sejarah, dan 9 siswa, sehingga jumlah seluruh responden dalam penelitian ini adalah 12 orang. Dalam hal ini, responden diminta untuk memberikan penjelasan melalui proses korespondensi seputar pembelajaran sejarah dan implementasi KTSP mata pelajaran sejarah. Responden juga diminta pendapatnya untuk memberikan penjelasan tentang kesulitan-kesulitan apa yang menjadi penghambat dalam penerapan KTSP mata pelajaran sejarah. Berdasarkan jawaban-jawaban responden tersebut digunakan sebagai data analisis untuk mendeteksi seputar realitas pembelajaran sejarah dan kesulitan-kesulitan dalam implementasi KTSP mata pelajaran sejarah.

Hasil analisis deskriptif terhadap hasil wawancara siswa, guru, dan pimpinan sekolah secara keseluruhan terhadap implementasi KTSP menunjukkan bahwa pembelajaran sejarah di SMA Prambanan Klaten sudah cukup baik meskipun dalam ilmplementasi KTSP menemui banyak kesulitan-kesulitan (G1, Wawancara 27 Juli 2012). Secara umum pelaksanaan pembelajaran sejarah menunjukkan bahwa: kinerja guru sejarah di SMA N I Prambanan Klaten dinilai cukup baik. Komponen materi pelajaran sejarah, metode pembelajaran, sarana pembelajaran, iklim kelas, dan 
motivasi belajar sejarah juga menunjukkan kualitas cukup baik. Sedangkan komponen sikap siswa dalam proses pembelajaran menunjukkan bahwa sikap siswa tersebut cukup baik (Observasi, 28 juli 2012).

Berdasarkan hasil observasi dan wawancara dengan siswa, sangat rasional apabila siswa menilai kinerja guru secara umum cukup mengingat pelaksanaan pembelajaran belum dikembangkan secara optimal. Kualifikasi salah satu guru adalah diploma, dalam pembelajaran juga masih menggunakan tradisi lama lebih didominasi oleh kegiatan ceramah guru sehingga siswa sering merasa bosan mengikuti pembelajaran sejarah (S1, Wawancara, 27 Juli 2012). Sedangkan komponen dan indikator kualitas yang lain, dalam hal ini materi pembelajaran, metode pembelajaran, sarana pembelajaran, iklim kelas, serta motivasi belajar siswa masuk klasifikasi baik (KS, Wawancara, 28 Juli 2012). Materi pelajaran menggunakan buku-buku yang telah distandarkan oleh BSNP sehingga masuk akal apabila siswa menilai baik.

Metode pembelajaran meskipun secara umum kinerja guru cukup baik, tetapi dalam hal implementasi metode sudah baik. Sarana pembelajaran berdasarkan hasil observasi sudah baik karena disamping memiliki perpustakaan yang juga menyediakan buku sejarah cukup lengkap juga memiliki TI yang dapat diakses untuk kegiatan pembelajaran (Observasi, 27 Juli 2012). Selanjutnya iklim kelas sudah baik menunjukkan iklim yang kondusif dan proses yang berjalan dengan baik. Demikian pula dengan motivasi belajar sejarah siswa juga baik terutama dalam tujuan untuk mendapatkan prestasi (S2, Wawancara, 25 Juli 2012). Sedangkan komponen dan indikator sikap siswa terhadap pelajaran sejarah menunjukkan klasifikasi yang cukup. Siswa menganggap pelajaran sejarah tidak begitu penting terbukti bahwa mata pelajaran sejarah tidak diujikan secara nasional (S8, Wawancara, 25 Juli 2012).

Berdasarkan wawancara dengan guru sejarah, mereka merasa bahwa selama ini telah melaksanakan pembelajaran sejarah secara maksimal. Komponen dan indikator kinerja guru dan materi pelajaran sejarah dinilai oleh guru sangat baik. Mereka sendiri menyadari bahwa anggapan yang kurang positif terhadap mata pelajaran sejarah menjadi kendala yang cukup serius untuk menggarap pembelajaran sejarah (G2, Wawancara, 26 Mei 2012). Di samping itu, keterbatasan jam pelajaran sejarah juga menjadi kendala dalam melaksanakan pembelajaran sejarah. Namun demikian, dengan segala keterbatasan itu guru yakin telah melaksanakan kewajiban secara sungguh-sungguh, termasuk mentransper nilai-nilai kesadaran sejarah dan nasionalisme pada siswa (G2, Wawancara, 26 Mei 2012). Demikian pula halnya dengan materi pembelajaran yang digunakan dan dikembangkan, sudah sangat baik dan mengacu pada standar isi sebagaimana digariskan oleh BSNP.

Sedangkan pelaksanaan metode pembelajaran menurut wawancara dengan guru dikatakannya sudah merasa baik. Itu menandakan bahwa guru merasa implementasi metode pembelajaran yang dilakukannya sudah baik. Berdasarkan hasil observasi, ada upaya-upaya guru untuk mengembangkan variasi metode pembelajaran. Tetapi variasi metode yang diterapkan terkadang tidak sesuai dengan keinginan siswa. Oleh karena itu di satu sisi ada sebagian siswa yang serius mengikuti pembelajaran, di lain sisi ada sebagian siswa yang asik ngobrol sendiri terutama siswa yang duduk paling belakang (Observasi, 27 Juli 2012). Selanjutnya komponen sarana pembelajaran guru menilai sama dengan 
penilaian siswa yakni klasifikasi cukup. Itu berarti bahwa sarana pembelajaran di SMA N I Prambanan Klaten belum lengkap atau cukup saja untuk kegiatan pembelajaran sejarah. Belum dikembangkan sarana pembelajaran yang secara khusus digunakan untuk pembelajaran sejarah. Belum adanya laboratorium IPS menunjukkan bahwa sarana pembelajaran sejarah belum dikembangkan secara proposional (Observasi, 27 Juli 2012).

Berdasarkan wawancara dengan kepala sekolah mengenai kinerja guru sejarah di SMA Negeri I Prambanan Klaten menunjukkan bahwa kinerja guru sudah baik (KS, Wawancara 27 Juli 2012). Itu berarti bahwa kinerja guru sejarah dinilai telah melaksanakan tugas dengan baik. Penilaian kepala sekolah berada pada posisi tengah yakni guru menilai sangat baik, sedangkan siswa menilai cukup baik. Meskipun sarana pembelajaran terbatas, guru berusaha untuk membuat media sederhana seperti peta konsep untuk melaksanakan pembelajaran sejarah. Di samping itu, guru selalu berusaha untuk menerapkan berbagai metode pembelajaran sehingga terlihat serius dalam melaksanakan tugas mengajar. Kepala sekolah juga menyadari bahwa porsi pengajaran sejarah yang semakin berkurang merupakan salah satu faktor penyebab guru kesulitan dalam mengembangkan pembelajaran. Di samping itu mata pelajaran sejarah yang tidak di ujikan secara nasional juga berdampak pada kurang maksimalnya perlakuan sekolah terhadap mata pelajaran sejarah. Demikian juga sikap siswa lebih serius mengikuti pelajaran-pelajaran yang diujikan secara nasional (KS, Wawancara, 27 Juli 2012).

Hasil wawancara guru terhadap implementasi komponen dan indikator hasil pembelajaran sejarah di SMA N I Prambanan Klaten menunjukkan bahwa kesadaran sejarah dan sikap nasionalisme siswa cukup baik. Kesadaran sejarah siswa dan sikap nasionalisme memiliki sudah diupayakan penanamannya meskipun belum sesuai dengan harapan. Fenomena ini memberikan gambaran bahwa kesadaran sejarah dan nasionalisme siswa belum sesuai dengan harapan tujuan pembelajaran sejarah. Mereka menilai bahwa kesadaran sejarah dan nasionalisme penting bagi generasi muda (S8, Wawancara, 28 Juli 2012), tetapi dalam penerapannya masih jauh dari harapan. Rendahnya sikap koletivitas menunjukkan bahwa rasa kebersamaan belum terwujud secara maksimal. Dalam upacara bendera setiap senin, sikap yang kurang positif sering ditunjukkan, bahkan tidak jarang siswa yang datang terlambat (G2, Wawancara, 26 juli 2012).

Kesulitan-kesulitan dalam Pengembangan KTSP

Penyusunan RPP

Dalam penyusunan Rencana Pelaksanaan Pembelajaran (RPP), guru sejarah masih kesulitan dalam pengembangannya karena berbagai faktor yakni: kurangnya pemahaman terhadap adanya otonomi guru yang memiliki kewenangan untuk mengambangkan RPP, kurangnya pemahaman terhadap Permendiknas No 42 tentang penyusunan RPP, terbatasnya referensi untuk pengembangan RPP, dan adanya kebingungan dengan model RPP yang bermacam ragam. Upaya yang mereka lakukan untuk mengatasi hambatan tersebut yang sekarang ini mereka usahakan adalah dengan diskusi dengan teman sejawat, seminar-seminar atau pelatihan-pelatihan ilmiah, membuka internet dengan belajar sendiri (G1, Wawancara, 26 Juli 2012). Di samping itu juga membandinkan beberapa RPP untuk kemudian memilih salah satu RPP yang mereka anggap paling baik untuk 
disusun sesuai dengan mata pelajaran yang menjadi tugasnya mengajar. Meskipun demikian, RPP yang disusun sendiri oleh guru sejarah terkadang masih belum sinkron antara tujuan pembelajaran, kegiatan pembelajaran, dan pelaksanaan evaluasinya. Padahal dalam sistem kegiatan pembelajaran antara tujuan pembelajaran, kegiatan pembelajaran, dan sistem evaluasi harus sinkron satu sama lainnya.

Menyiapkan Materi Pembelajaran

Guru sejarah belum maksimal dalam menyiapkan materi pelajaran sebelum melaksanakan pembelajaran. Pemahaman cara mengemas materi pelajaran sebagai tuntutan Kurikulum Tingkat Satuan Pendidikan (KTSP), dimana guru harus mengembangkan seluruh proses kegiatan pembelajaran termasuk bahan ajar atau materi pelajaran belum difahami secara baik. Guru sekedar menggunakan buku-buku teks pelajaran yang tidak dikemas dalam pelaksanaan pembelajaran (S8, wawancara 27 Juli 2012). Padahal tugas guru salah satu tuntutan undang-undang adalah mampu mengembangan materi pembelajaran baik yang mencakup kompeksitas dan keluasan, maupun yang menyangkuat pengorganisasian materi agar mudah diterima oleh siswa. Adapun usaha-usaha yang dilakukan untuk mengatasi kesulitan tersebut adalah melalui diskusi dengan teman sejawat, ikut pelatihan-pelatihan, dan kegiatan-kegiatan lain yang memberi pengalaman untuk mengembangkan materi pelajaran.

Menggunakan Media Pembelajaran

Masalah media pembelajaran merupakan permasalahan umum di hampir setiap sekolah yang belum dikembangkan secara maksimal baik oleh sekolah secara kelembagaan, maupun oleh guru itu sendiri. Hal ini disebabkan oleh kurangnya pemahaman akan arti penting media pembelajaran sebagai sarana penyampai informasi pada siswa. Kebanyakan sekolah masih belum memiliki LCD, komputer khusus untuk kegiatan pelajaran, demikian juga dengan akses internet. Media-media yang dimiliki masih tradisional, itupun belum dikembangkan secara maksimal oleh guru. Para guru juga masih menunjukkan rutinitas dalam pelaksanaan pembelajaran, sebagai wujud sekedar melaksanakan kewajiban mengajar. Namun demikian terdapat juga beberapa usaha guru dalam mengembangkan media pembelajaran seperti membuat peta konsep menggunakan kertas manila, kartu-kartu media permainan, mengembangkan peta, dan media-media lain yang dianggap penting. Adapun upaya-upaya yang dilakukan oleh guru untuk mengembangkan media pembelajaran adalah melalui pelatihan-pelatihan pembuatan dan pengembangan media, dan mendorong sekolah untuk membiayai atau mengalokasikan anggaran untuk pengembanan media pembelajaran yang disusun dalan rencana program sekolah $(\mathrm{G} 1$, G2, Wawancara, 26 Juli 2012).

Memfokuskan Perhatian Siswa

Secara umum siswa SMA adalah masa bimbang, sehingga dalam kegiatan pembelajaran perhatian siswa kurang terfokus pada kegiatan pembelajaran. Siswa kurang konsentrasi dalam pembelajaran seperti berbicara dengan teman sebelahnya, ribut sendiri, ngantuk-ngantuk karena kelelahan, dan bahkan ada pula yang memang sengaja ingin mencari perhatian guru. Apalagi jika metode mengajar guru hanya ceramah belaka, maka anak terkadang merasa bosan (KS, Wawancara, 28 Juli 2012). Terlebih lagi pada pelajaran siang hari, siswa sudah tampak tidak betah di kelas karena lapar dan ingn segera pulang sekolah. Upaya-upaya yang dilakukan guru selama ini adalah melalui upaya menciptakan suasana 
yang menyenangkan seperti dengan lelucon, menampilkan gambar-gambar yang lucu sehingga perhatian anak terfokus pada gambar karena merasa tertarik, selanjutnya baru menjelaskan arti dan makna gambar tersebut. Di samping itu juga melalui permainan-permainan yang mendorong motivasi siswa untuk ikut berpartisipasi dalam permainan dan dapat mendorong rasa senang di kalangan siswa.

Menerapkan Variasi Metode Pembelajaran

$$
\text { Metode pembelajaran yang }
$$

diterapkan oleg guru-guru kebanyakan belum menunjukkan variasi dalam implementasinya, sehingga metode belum berkembang secara baik. Sebenarnya metode cukup banyak tetapi yang dikuasai sepertinya itu-itu saja, sehingga terasa membosankan bagi anak. Penyebabnya karena kurangnya pemahaman guru tentang metode yang sedang berkembang dan banyak digunakan di kota-kota, rasa enggan guru untuk mengembangkan metode yang memerlukan perangkat pendukung yang rumit, dan metode-metode yang memerlukan waktu khusus dan panjang (G1, Wawancara, 27 Juli 2012). Adapun upaya-upaya yang dilakukan untuk mengatasi hambatan tersebut adalam melalui pelatihan-pelatihan metode pembelajaran, diskusi dengan teman sejawat, kepala sekolah, dan juga pengawas sekolah.

Memberikan Umpan Balik (feed back)

Umpan balik dalam kegiatan pembelajaran untuk menyelami seberapa jauh penguasaan siswa terhadap materi pembelajaran sangat penting dilakukan oleh guru. Dalam pelaksanaannya guru masih kesulitan memberikan umpan balik pada anak, baik selama proses pembelajaran berlangsung, maupun setelah materi pembelajaran selesai diberikan. Hal ini disebabkan oleh beberapa faktor seperti waktu pembelajaran yang sudah habis, siswa yang kurang tertarik pada materi pembelajaran, dan masalah-masalah lain yang menyebabkan guru merasa kesulitan untuk melakukan umpan balik. Selama ini usaha-usaha yang dilakukan guru adalah dengan mengelola waktu pembelajaran secara efektif dan efisien, serta melakukan umpan balik di sepanjang proses pembelajaran berlangsung. Hal ini dilakukan seperti dengan usaha menyelami apakah anak sudah menguasai materi atau belum, pemberian kesempatan untuk bertanya, dan atau dengan memberikan pertanyaan untuk dijawab oleh siswa dan diikuti oleh siswa lain saling melengkapi (S3, S4, Wawancara, 27 Juli 2012).

Memberikan Rangsangan Motivasi

Untuk mencapai tujuan pembelajaran sejarah secara lebih baik, maka pemberian motivasi belajar pada siswa menjadi sangat penting karena keberhasilan pencnapaian tujuan pembelajaran adalah melalui penanaman motivasi belajar pada siswa. Apalagi pada suatu kelas di mana kemampuan anak berbeda-beda, maka akan kesulitan dalam memberi motivasi terutama pada siswa yang kemampuannya rendah jika dibandinkan dengan siswa lain. Bahkan juga karena faktor lain yang sensitif seperti latarbelakang ekonomi dan sosial orang tua, faktor keberanian, dan lain sebagainya. Usaha-usaha yang dilakukan oleh guru adalah melalui pengelompokan siswa melalui teknik pembagian tempat duduk misalnya anak yang kurang pandai diberi tempat duduk bersama siswa yang landai sehingga mereka termotivasi untuk belajar. Bentuk lain juga dilakukan guru seperti menanamkan arti penting pelajaran bagi kehidupan riil siswa dalam keluarga dan masyarakat (S1, S2, S5, Wawancara, 27 Agustus 2012).

Mengevaluasi Pembelajaran Secara Komprehensif 
Guru sejarah merasa kesulitan dalam melakukan evaluasi secara menyeluruh. Pada umumnya, evaluasi hanya dilakukan terhadap kemampuan kognitif siswa, sementara yang menyangkut apektif dan psikomotorik belum banyak dievaluasi (G2, Wawancara 27 Juli 2012). Oleh karena itu pembelajaran pada umumnya masih terfokus pada usaha penguasaan ranah kognitif seperti hapalan dan pengetahuan belaka, semenara arti penting materi pelajaran bagi kehidupan anak di keluarga dan di masyarakat kurang tersentuh. Keadaan seperti ini di disebabkan oleh faktor intern dan ekstern yang mengkondisikannya seperti kurangnya pemahaman guru mengenai sistem evaluasi yang baik serta keengganan menyusun instrumen evaluasi untuk mengevaluasi secara kemampuan siswa secara menyeluruh, dan faktor kebijakan pemerintah sampai kepala sekolah yang menkondisikan evaluasi hanya menyentuh ranah kognitif dan apektif yang terbatas. Kebijakan sekolah belum mengarah pada usaha penilaian psikomotorik secara memadai terlebih pada mata pelajaran-pelajaran sosial. Padahal kehidupan riil siswa adalah kehidupan sosial, sehingga perkembangan perilaku siswa harus dievaluasi secara berkelanjutan. Adapun upaya-upaya yang dilakukan oleh guru sejarah adalah melalui pelatihan-pelatihan evaluasi atau sistem penilaian dan berusaha memahami bagaimana penyusunan instrumen yang baik untun diterapkan, dan juga melalui pertemuan-pertemuan dengan teman sejawat baik di tingkat sekolah maupun lintas sekolah (G1, Wawancara 27 Juli 2012) yang mendiskusikan mengenai teknik-teknik evaluasi yang baik.

Mengembangkan KTSP

Secara umum, pemahaman guru tentang KTSP masih sangat terbatas. Guru sejarah belum bisa mandiri dalam mengembangkan kurikulum baik yang menyangkut pengembangan materinya, perencanaan dan penyusunan perangkat pendukungnya, implementasinya, maupun pelaksanaan sistem evaluasinya. Dampaknya, KTSP hanya menjadi barang mati yang dikembangkan hanya wadahnya saja, sementara substansi dan materinya sepenuhnya mengikuti rambu-rambu yang standar dari pemerintah. Dalam konteks pengembangan seharusnya guru mampu mengembangkan materi melalui pengayaan kasus-kasus lokal dan nasional lain yang lebih memberikan pengalaman bagi peserta didik. Demikian juga dengan penyusunan perangkat pembelajaran, guru sejarah seharusnya otonom dalam menyusun dan mengembangkan perangkat pembelajaran seperti RPP, bahan ajar, silabus, dan lain sebagainya, tetapi masih terlihat kebingungan, dan pada akhirnya hanya mencontoh model yang sudah jadi dari orang lain. Begitu juga dalam implementasi dalam kegiatan pembelajaran belum menunjukkan adanya usaya serius untuk mandiri dan lebih baik, demikian juga dengan pelaksanaan sistem evaluasi yang instrumen dan pengembangannya menjadi wilayah otonomi guru. Bahkan pengawas sekolah dan kepala sekolah masih mendikte guru untuk mengikuti arah kebijakan dan tuntutannya ketimbang melihat substansi dan kewenangan guru sebagimana tuntutan undang-undang yang memberikan otonomi pada guru, sementara pengawas dan kepala sekolah adalah komponen pengontrol saja yang menjamin kualitas pembelajaran yang dilaksanakan dan dikembangkan oleh guru.

\section{Penutup}

Pembelajaran sejarah di SMA N I Prambanan Klaten menunjukkan kecenderungan pembelajaran yang sifatnya rutinitas, kurang memperhtikan kualitas 
proses dan hasil yang substantif sesuai dengan rumusan tujuan pembelajaran sejarah sebagaimana termuat dalam Permendiknas No 22 tahun 2006. Metodologi pembelajaran meskupun secara umum cukup baik, tetapi masih tampak hal-hal yang masih perlu dibenahi, terutana perkembangan metodemetode pembelajaran yang semakin dinamis. Aspek-aspek yang menyangkut motivasi siswa dalam belajar sejarah, sikap siswa terhadap pelajaran sejarah, serta suasana pembelajaran perlu diupayakan untuk lebih baik dan lebih kondusif. Demikian halnya yang terkait dengan evaluasi pembelajaran sejarah, yang masih terfokus pada evaluasi penguasaan ranah kognitif, sementara tujuan pembelajaran lain yang menyangkut kesadaran sejarah dan nasionalisme belum dievaluasi. Dampaknya, evaluasi belum dileksanakan secara menyeluruh atau komprehensif.

Dalam implementasi KTSP guru sejarah masih menemukan banyak kesulitankesulitan baik secara teoritik maupun praktik. Adapun kesulitan-kesulitan yang dialami guru dalam pembelajaran sejarah yang menyangkut implementasi KTSP adalah: (1) kesulitan dalam mengembangkar Rencana Pelaksanaan Pembelajaran, (2) menyiapkan atau mengemas materi pembelajaran, (3) menggunakan media yang mtakhir, (4) memfokuskan perhatian siswa, (5) menerapkan variasi metode pembelajaran, (6) memberikan umpan balik, (7) memberikan rangsangan motivasi, (8) mengevaluasi pembelajaran secara komprehensif, dan (9) mengembangkan secara keseluruhan KTSP itu sendiri.

\section{Ucapan Terima Kasih}

Dalam kesempatan ini, penulis mengucapkan terima kasih kepada berbagai pihak yang telah membantu terlaksananya penelitian ini. Tak lupa, penulis juga menyampaikan ucapan terima kasih kepada dewan redaksi Jurnal Istoria terbitan Pendidikan Sejarah, Fakultas Ilmu Sosial, Universitas Negeri Yogyakarta atas kesempatan yang diberikan sehingga tulisan ini dapat dipublikasikan pada edisi Maret 2015.

\section{Daftar Pustaka}

Banathy, Bela H. (1992). A Systems View of Education: Concepts and Principles for Effective Practice. Englewood Cliffs: Educational Technology Publications.

Budiono dan Ella Yulelawati. (1999). "Penyusunan Kurikulum Berbasis Kemampuan". Jurnal Pendidikan dan Kebudayaan, No.019, Tahun Ke5 Iktober 1999. Jakarta: Balitbang Depdiknas.

Davidoff, LL. (1988). "Introduction To Psychology", alih bahasa Mari Juniati, Psikologi Suatu Pengantar Jilid I. Jakarta: Erlangga.

Departemen Pendidikan dan Kebudayaan, (1995). Kamus Besar Bahasa Indonesia Edisi Kedua. Jakarta: Balai Pustaka.

Freire, Paulo. (1999). Politik Pendidikan: Kebudayaan, Kekuasaan, dan Pembebasan. Terj. Agung Prihantoro. Yogyakarta: Pustaka Pelajar.

Gunning, Dennis. (1978). The Teaching of History. London: Cronhelm.

Hariyono. (1992). "Pengajaran Sejarah dan Egenwelt Subjek-Didik". Historika. 
Surakarta: PPs Pendidikan Sejarah IKIP Jakarta KPK UNS.

Kartodirdjo, Sartono.(1982). Pemikiran dan Perkembangan Historiografi Indonesia: Suatu Alternatif. Jakarta: PT Gramedia.

Krippendorff, Klaus. (1991). Content Analysis: Introduction Its Theory and Methodology", Alih Bahasa Farid Wajidi, Analisis Isi: Pengantar Teori dan Metodologi. Jakarta: Rajawali.

Maarif, Ahmad Syafii.

(1995). "Historiografi dan Pengajaran Sejarah". Makalah. Padang: FPIPS IKIP Padang.

Miles, M.B. and Huberman, A.M. (1984). Qualitative Data Analysis: A Sourcebook of New Methods. Beverly Hills CA: Sage Publications.

Moedjanto, G. (1999). "Reformasi Pengajaran Sejarah Nasional". Kompas. 1 Mei 1999.

Moleong, L.J. (1999). Metodologi Penelitian Kualitatif. Bandung: Remaja Rosdakarya.

Muhadjir, Noeng. (1996). Metodologi Penelitian Kualitatif. Yogyakarta: Rake Sarasin.

Patton, M.Q. (1980). Qualitative Evaluation Methods. Beverly Hills, CA.: Sage Publication.

Saylor, J.G. (1981). Curriculum Planning for Better Teaching and Learning, Fourth Edition. Japan: Holt.
Soedjatmoko. (1976). "Kesadaaran Sejarah dalam Pembangunan”. Prisma No. 7. Jakarta.

Spradley, J.P. (1980). Participant Observation. New York, N.Y.: holt, Rinehart, and Winston.

Surakhmad, Winarno. (2000). Metodologi Pengajaran Nasional. Jakarta: UHAMKA.

Sutopo, H.B. (1995). Kritik Seni Holistik Sebagai Model Pendekatan Penelitian Kualitatif. Surakarta: UNS Press.

Sutopo, H.B. (1996). Metodologi Penelitian Kualitatif. Surakarta: Jurusan Seni Rupa Fakultas Sastra UNS.

Suud, Abu. (1994). "Format Metodologi Pengajaran Sejarah Dalam Transformasi Nilai dan Pengetahuan". Makalah. Seminar Nasional Memantapkan Format Metodologi Pendidikan Sejarah dan Sosialisasi Kurikulum 1994. Yogyakarta: IKIP Yogyakarta.

Waluyo, H.J. (2000). "Hermeneutik Sebagai Pusat Pendekatan Kualitatif", dalam Historika, No.11. Surakarta: PPS UNJ KPK UNS.

Winataputera, US. (1992). Model-Model Pembelajaran. Jakarta: Depdikbud.

Yin, R.K. (1987). Case Study Research: Design and Methods. Beverly Hills, CA: Sage Publication. 
Volume 10 No 2 Maret 2015

Zamroni. (2000). Paradigma Pendidikan Masa Depan. Yogyakarta: PT Bayu Indra Grafika. 